\title{
The role of biological and economic factors in urban population growth
}

\author{
N. V. Shcherbakova
Scientific Research and Design Institute of Territorial Development and Transport Infrastructure, \\ N. V. Shcherbakova
Scientific Research and Design Institute of Territorial Development and Transport Infrastructure, \\ St.Petersburg, Russia; email: nadshch@mail.ru
}

\begin{abstract}
This paper explores the influence of biological mechanisms in overpopulated territories on urban growth and addresses the question how biological factors correlate with economic factors, such as GDP growth, in this process. The article provides an overview of the approaches in regional economics, ethology and demography to this problem. To analyze the influence of biological and economic factors on urbanization, four hypotheses are formulated. To test these hypothesis, methods of regression analysis are applied to the statistical data of the United Nations and the World Bank for 132 countries for $1995,2005,2015$. The analysis shows that the biological mechanisms of population reduction play a significant role in the least and less developed countries. Per capita GDP growth leads to an increase in the concentration of population in big cities (with the population of 1 million inhabitants or more). The total fertility rate varies significantly in these countries, but as the population starts to grow, fertility begins to fall gradually. In more developed countries with a high per capita GDP level, the share of urban population tends to shrink, while the total fertility rate stabilizes there at the level of ca. 1.0-2.0 births per woman.
\end{abstract}

\section{Рост численности городского населения: биологический фактор}

\author{
Н. В. Щербакова \\ Научно-исследовательский и проектный институт территориального развития \\ и транспортной инфраструктурь, Санкт-Петербург, Pоссия; e-mail: nadshch@mail.ru
}

\begin{abstract}
АННОТАЦИЯ
В статье исследуется, оказывают ли биологические механизмы, вызванные перенаселением территории, существенное влияние на рост городов, и является ли уровень экономического развития страны значимым при влиянии биологических механизмов. С целью анализа влияния биологических и экономических факторов на процессы урбанизации сформулированы четыре гипотезы, основанные на теоре тических утверждениях и эмпирических выводах региональной экономики, этологии и демографии. Результаты регрессионного анализа статистических данных на национальном уровне, примененные для проверки этих гипотез, показывают, что биологические факторы городского развития следует рассматривать наравне с экономическими, но необходим комплексный анализ. Биологические механизмы сокращения численности населения играют важную роль в наименее развитых и развивающихся странах. С ростом ВВП на душу населения в этих странах увеличивается концентрация населения в крупных городах (с населением 1 млн человек и более). Общий коэффициент рождаемости в этих странах значительно различается, но с ростом населения он постепенно снижается. В развитых странах с высоким уровнем ВВП на душу населения доля жителей крупных городах в общей численности населения страны имеет тенденцию к снижению, и общий уровень рождаемости стабилизируется на уровне около $1,0-2,0$ родов на одну женщину.
\end{abstract}

(c) N.V. Shcherbakova, 2019

\section{KEYWORDS}

urbanization, overpopulation, fertility rate, birth rate, population density, level of economic development

\section{FOR CITATION}

Shcherbakova N. V. (2019) The role of biological and economic factors in urban population growth. R-economy, 5(3), 103-114. doi: $10.15826 /$ recon.2019.5.3.011

\section{КЛЮЧЕВЫЕ СЛОВА}

урбанизация, перенаселение, коэффициент рождаемости, рождаемость, плотность населения, уровень экономического развития

\section{ДЛЯ ЦИТИРОВАНИЯ}

Shcherbakova N. V. (2019) The role of biological and economic factors in urban population growth. R-economy, 5(3), 103-114. doi: 10.15826/recon.2019.5.3.011 


\section{Introduction}

Urban economics explains the formation of cities and their growth in terms of endogenous and exogenous factors, which include access to public good, scale and localization economies, product differentiation, multiplicative effect of industrial development, and location advantages (e.g. proximity to transport nodes). At the same time, the biological factors affecting urban development largely remain underexplored in modern research literature.

However, the interdisciplinary approach to the problem of urban growth, in particular the one that combines the perspective of human ethology and demography, is also interesting and holds much promise. Human ethology studies the behaviour of humans as social animals and, therefore, it looks the growth of urban population in the light of such problems as the scarcity of natural resources and the overpopulation of our planet. The permanently deteriorating conditions of rural life make people move to cities and towns. The biological mechanisms of population decline lead to urbanization, which in a natural way reduces fertility. In their turn, demographers observe lower fertility rates in cities in comparison with less densely populated areas.

Biological mechanisms often induce people to act against their economic interests and in ways that seem to be contradictory to the common sense. In economic literature, however, biological mechanisms are considered of minor importance, whereas economic incentives, such as the cost-benefit principle, are expected to prevail. Thus, the theoretical premises of urban economics can be expanded by adding the biological factor to the analysis of urban development. The overpopulation of a certain territory leads to urban growth, while in cities the fertility rate of population reduces.

The aim of this research is to investigate how big is the influence of the biological factor on cities' growth by using the statistical data for different countries. The key question this study addresses is whether overpopulation of a territory really leads to urbanization, and whether in urban areas the fertility rate decreases. Another important question of this research is how biological factors correlate with economic factors, such as GDP growth, in this process.

The paper is organized as follows. The second section provides an overview of the main approaches of regional and urban economics, ethology, and demography, which explain urban growth by taking into account biological factors. This section also contains the main hypotheses of this study. The third section describes the statistical data and the main indicators used in the analysis. In the fourth section, the hypotheses are tested by applying methods of regression analysis. The final section contains the conclusions.

\section{Theoretical framework}

Emergence and growth of cities is explained in regional and urban economics by applying approaches developed within conventional urban economics, the theory of industrial organization, the New Economic Geography, the theory of endogenous economic growth, and so on (for more detail see, for example, [1]).

However, in the context of this research it is worth pointing out that in economic literature, biological factors are mentioned only briefly. Natural limitations are sometimes discussed, for example, when considering urban-rural linkages. Due to shortages of working places, famines caused by natural crop failure in rural areas and so on, many people have to move to the city in search of better opportunities $[2 ; 3]$. This kind of urban growth is especially typical of developing countries.

At the same time, the emergence and development of cities was impossible without the rise in agriculture surplus generated by the technological progress $[4 ; 5]$ Nowadays technological and scientific development has made it possible to produce enough food for cities with the help of labour-saving technologies. In the USA, where incomes are especially high in agriculture, farmers with their families make up $1 \%$ of the country's population, but they supply the rest $99 \%$ of population with foodstuffs [6].

Therefore, it is possible to conclude that redundancies in rural areas contribute to urban development. This idea was mentioned by many theorists of regional economics [4], but, unfortunately, it has not received enough attention in research literature.

In ethology, cities, especially big ones, are considered as collapsing gatherings and as a relatively harmless way of decreasing the population size [7]. When the population size reaches its critical level and the territory becomes too densely populated, this activates the biological mechanisms that lead to a decrease in the population density such as epidemics, a rise in interpersonal aggression and violence. Other mechanisms, including collapsing 
gatherings, have a more gentle effect. It is important to emphasize that the second group of biological mechanisms come into force before the essential resources, in particular food, are exhausted [8-10].

Studies on the influence of high population density on animals' behaviour were carried out on many species, such as the rats [11], insects (for example, the Mediterranean fruit fly [12]), and birds [9]. One of the first studies of this kind was John B. Calhoun's experiment on rats. Its results were published in 1962 [11]. He discovered that overcrowding among rats lead to pathological behaviours, such as increased aggression, violation of sexual relations (same-sex relations, rapes of female individuals, simplification or total disappearance of marriage rituals), and decrease in care for posterity. The essential consequences of high density were the declining birth rates and rising death rates. At the same time, those males with their females who managed to claim up to the top of the hierarchical ladder had a normal way of life, which means in some sense that hierarchy is able to soften the pressure of overcrowding and to increase environment capacity $[9 ; 13]$.

Calhoun's work aroused a large resonance in scientific world and inspired many scientists to research the problem of overcrowding from different aspects, including the challenges of living in large, densely populated cities and ways of dealing with these pressures [14]. Following Calhoun's research, Jonathan Freedman began the first laboratory studies of crowding among human beings at Stanford University in the late 1960s [15]. He sought the correlation between density and a variety of pathologies similar to those found in Calhoun's laboratory. His concluded that crowding per se did not automatically lead to pathological behaviour. We cannot solve modern urban and environmental problems by merely reducing the density in the areas we inhabit, but we cannot ignore the fact that the population density does contribute to these problems [16].

One of the central questions in these studies is how relevant are the results of animal experiments for humans [10]. There are two opposite views on this problem: one point of view is that these results cannot be applied to human beings, because humans are a social species and, therefore, a high concentration of individuals within one area might not have a negative effect on their behaviour [8]. In other words, unlike rates in Calhoun's experiment, people are able to cope with overpopulation [14].
Other scholars, including the author of this paper, consider these results to be applicable to humans, pointing out that biological mechanisms are shared by animals and humans alike since they do not require rational decision-making [7]. Each physical contact of individuals of the same species, including human beings, is a stimulus for the release of a small amount of adrenaline, which means that there should be a limit to the load a person can endure [5]. Humans did not use to live in huge conglomerations, numbering thousands of individuals. Our behaviour is adapted for living in small tribal groups of little less than one hundred individuals [17]. Behaviour aimed at avoiding excessive contacts allows us to limit the number of people we interact within the necessary limit.

In big cities, where life is stressful, it is problematic to pursue only healthy forms of human behaviour, which causes aggression, isolation and indifference to others, alienation and a loss of individuality [18]. No wonder that the "prevalence of hypertension rose with urbanization" [19]. Despite all our technical achievements, we are still an elementary phenomenon in a biological sense [20]. The iron wall of anthropocentrism prevents us from realizing our natural inclinations [10]. No matter how sophisticated we consider ourselves to be, if the population density rises above a certain limit, when the number of people exceeds the number of the available social roles, it might cause violence and destruction of social structures.

Nevertheless, urban life also holds a number of advantages: interactions within close urban communities enhance people's mental abilities. Another important advantage of the supertribal conditions is that people enjoy relative freedom in their choice of activities [17].

There are also many demographic facts that confirm the arguments that the results of animal experiments indeed are applicable to humans. A lot has been said about the sharp fall in the fertility rates for urban population, accompanied by alienation and indifference to children [10]. Two competing hypotheses are elaborated to explain this fact: compositional and contextual [21]. The compositional hypothesis suggests that fertility levels vary between places simply because different people live in different settlements (e.g., more educated people, students, married people live in cities), whereas the contextual hypothesis suggests that factors related to the immediate living environment are of critical importance. The immediate living environment in cities is deter- 
mined by such factors as high costs of raising children, the lack of opportunities to improve their housing conditions, more individual autonomy and self-actualisation, leading to more rational individual choices, which usually results in people having fewer children.

There are studies that explore the regional difference in terms of fertility rates and associated factors for specific countries: Great Britain [22], Nigeria [23], Finland and other European countries [21], the USA [24], Switzerland [25], etc. All these studies indicate that the fertility rate is influenced by a set of factors (female education and employment, age at first marriage, birth control, family structure, housing conditions). These factors (and the population density is among them) also determine the differences between the urban and rural population. The more densely an area is populated, the lower the fertility rate is. All these factors have an objective character and it is hard to control them through state regulation, for example, through birth-control programs [25]. Furthermore, studies show that in many countries the urban-rural fertility variation has decreased over time, but significant differences between various settlements still persist $[21 ; 23]$.

It is worth mentioning that many developing countries are characterized by high fertility rates even in urban areas, which results in rapid population growth. High fertility rates used to be necessary to compensate for high infant mortality rates but now, thanks to humanitarian aid, these countries are experiencing decline in the infant mortality rates, whereas their fertility rates require more time to decrease accordingly. In sustainable populations, the fertility rate normally conforms with the infant mortality rate [7].

Dolnik states that there is no strict dependence between poverty and fertility, pointing out that "poverty" and "wealth" are vague concepts even in economy and sociology [7]. There cannot be a strict causal relationship between such subjective and short-term notion as poverty and the long-term population response (fertility rate).

Our literature review has led us to the following conclusions:

1. Although the influence of biological factors on cities' formation and development is not denied in urban economics, they are considered to be of minor importance while the priority is given to economic factors. However, the behaviour of economic agents can take irrational forms due to the impact of biological factors.
2. The influence of biological mechanisms on the regulation of animals' population size is an established fact. One of such mechanisms - collapsing gatherings - leads to the concentration of individuals within a limited territory. When the population density becomes high, the fertility rate decreases and the population size starts to shrink as well, which usually happens in the second generation.

3. The possibility of applying the results of animal experiments of high-density living to human beings is still a debatable question, although the fact that the fertility rate decreases due to the growth in population density is widely acknowledged in demography.

We have formulated the following hypotheses:

Hypothesis 1: There is a direct relationship between the population density and urban growth.

Hypothesis 2: Urban population growth is accompanied by a fall in the fertility rate.

Hypothesis 3: There is no correlation between poverty and fertility.

Hypothesis 4: Population concentration in big cities and the relationship between the birth rates and the infant mortality rates depend on the level of economic development.

\section{Methods and data}

To test the above-described hypotheses, this study uses the method of regression analysis. One factor regression is taken into account. Multiple regression models are not included in this paper because, as statistical analysis has shown, all of the considered multifactor models can be reduced to one factor regression model. Among the types of models under consideration are simple regression models, such as linear, exponential, square root, squared, logarithmic, reciprocal, multiplicative models and polynomial regression models (of the second order).

Most of the statistical calculations within the scope of regression analysis are made with the help of "Statgraphics 18" software. The data of the United Nations and the World Bank for 132 countries for 1995, 2005, 2015 are selected for the analysis because of their availability and relative sufficiency ${ }^{1}$. The coverage of the countries is as

\footnotetext{
1 World Bank, World Development Indicators (https:// data.worldbank.org); United Nations, Department of Economic and Social Affairs, Population Division. Demographic Yearbook 2016, 2011, 2006, 2001, 1996. Online Editions (https:// unstats.un.org); United Nations, Department of Economic and Social Affairs, Population Division (2018). World Urbanization Prospects: 2018 Revision, Online Edition (https://esa.un.org)
} 
maximal as possible, but it is limited by the availability of the relevant data. We take the years of 1995, 2005 and 2015 in order to reveal the dynamics in the indicators within a ten-year period. The choice of the years and the interval is determined by the availability of the source data and the aim of this research.

The countries are classified according to their level of economic development. The level of GDP per capita in current prices is chosen as the main criteria and, therefore, the countries are divided into three groups: more developed, less developed and the least developed countries. This division of the countries is based on the following relative principles: per capita GDP of more developed countries equals or exceeds the doubled average value of this indicator; per capita GDP of the least developed countries equals or is below the median value of this indicator. These are relative criteria of classification, but they enable us to use the available statistical information.

As GDP was gradually growing in all countries of the world, in 1995, 2005 and 2015 the boundary values were different. In 1995, developed countries had per capita GDP of more than 15,400 US dollars. In less developed regions, per capita GDP varied between 2,101 and 15,400 US dollars. The least developed countries had per capita GDP of or less than 2,100 US dollars. In 2005, more developed countries had per capita GDP more than 25,000 US dollars; less developed countries, more than 3,500 but equal or less than 25,000; and the least developed countries, 3,500 or less. In 2015, more developed countries had per capita GDP more than 30,000 US dollars; less developed countries, more than 5,800 but equal or less than 30,000; and the least developed countries, 5,800 or less.

In the next section we are going to test the four hypotheses by applying regression analysis and the above-described indicators.

\section{Results}

To prove our first hypothesis, we need to show that urban growth is a consequence of high population density. Urbanization (urban growth) can be measured as a level of urban population relative to the total population of this area (a static indicator) or as the rate of urban population growth (a dynamic indicator). Both indicators can be expressed in percentage terms. We need to look at the relations between the following indicators: the average annual rate of change of urban population in a country and its population density; the share of urban population in the total population of a country and the population density. Regression analysis showed that there is no statistically significant relationships between these indicators in all the considered years (see Table 1).

To test the second hypothesis, we considered the relationship between the fertility rate and the share of urban population in the total population of a country. Regression analysis showed that there is a moderately strong relationship between the two variables in all the considered years (see Table 2). In 1995 and 2005, the best model fitting

Table 1

Results of regression analysis (first hypothesis test)

\begin{tabular}{|c|c|c|c|c|c|c|c|c|c|}
\hline \multirow{2}{*}{$\begin{array}{l}\text { Dependent } \\
\text { variable }(y)\end{array}$} & \multirow{2}{*}{$\begin{array}{l}\text { Indepen- } \\
\text { dent vari- } \\
\text { able }(x)\end{array}$} & \multirow[t]{2}{*}{ Year } & \multirow{2}{*}{$\begin{array}{l}\text { Correla- } \\
\text { tion coef- } \\
\text { ficient }\end{array}$} & \multirow[t]{2}{*}{ Regression model } & \multirow{2}{*}{$\underset{\%}{\text { R-squared, }}$} & \multicolumn{2}{|c|}{ T-statistic (P-value) } & \multirow{2}{*}{$\begin{array}{c}\text { F-ratio } \\
\text { (P-val- } \\
\text { ue) }\end{array}$} & \multirow{2}{*}{$\begin{array}{l}\text { Durbin- } \\
\text { Watson } \\
\text { statistic } \\
\text { (P-value) }\end{array}$} \\
\hline & & & & & & Intercept & Slope & & \\
\hline \multirow{3}{*}{$\begin{array}{l}\text { Average } \\
\text { annual rate } \\
\text { of change of } \\
\text { the urban } \\
\text { population, } \\
\text { percent }\end{array}$} & \multirow{3}{*}{$\begin{array}{l}\text { Population } \\
\text { density, } \\
\text { inhabitants } \\
\text { per square } \\
\text { km }\end{array}$} & 1995 & -0.14 & $\begin{array}{l}\text { Square root-X model: } \\
y=3.06-0.02 \sqrt{x}\end{array}$ & 1.8 & $\begin{array}{c}15.9 \\
(0.000)\end{array}$ & $\begin{array}{c}-1.9 \\
(0.061)\end{array}$ & $\begin{array}{c}3.6 \\
(0.061)\end{array}$ & $\begin{array}{c}1.5 \\
(0.000)\end{array}$ \\
\hline & & 2005 & -0.10 & $\begin{array}{l}\text { Square root-X model: } \\
y=2.13-0.01 \sqrt{x}\end{array}$ & 1.0 & $\begin{array}{c}13.7 \\
(0.000)\end{array}$ & $\begin{array}{c}-1.4 \\
(0.160)\end{array}$ & $\begin{array}{c}2.0 \\
(0.160)\end{array}$ & $\begin{array}{c}1.6 \\
(0.001)\end{array}$ \\
\hline & & 2015 & -0.06 & $\begin{array}{l}\text { Reciprocal-X model: } \\
y=1.79-\frac{0.04}{x}\end{array}$ & 0.4 & $\begin{array}{c}12.9 \\
(0.000)\end{array}$ & $\begin{array}{c}-0.8 \\
(0.450)\end{array}$ & $\begin{array}{c}0.6 \\
(0.450)\end{array}$ & $\begin{array}{c}1.4 \\
(0.000)\end{array}$ \\
\hline \multirow{3}{*}{$\begin{array}{l}\text { Urban } \\
\text { population, } \\
\text { percentage } \\
\text { of the total } \\
\text { population }\end{array}$} & \multirow{3}{*}{$\begin{array}{l}\text { Population } \\
\text { density, } \\
\text { inhabitants } \\
\text { per square } \\
\text { km }\end{array}$} & 1995 & -0.08 & $\begin{array}{l}\text { Square root-X model: } \\
y=54.34-0.35 \sqrt{x}\end{array}$ & 0.7 & $\begin{array}{c}11.8 \\
(0.000)\end{array}$ & $\begin{array}{c}-0.8 \\
(0.450)\end{array}$ & $\begin{array}{c}0.6 \\
(0.450)\end{array}$ & $\begin{array}{c}0.9 \\
(0.000)\end{array}$ \\
\hline & & 2005 & 0.05 & $\begin{array}{c}\text { Linear model: } \\
y=56.35-0.01 x\end{array}$ & 0.2 & $\begin{array}{c}19.0 \\
(0.000)\end{array}$ & $\begin{array}{c}0.4 \\
(0.670)\end{array}$ & $\begin{array}{c}0.2 \\
(0.670)\end{array}$ & $\begin{array}{c}0.6 \\
(0.000)\end{array}$ \\
\hline & & 2015 & -0.19 & $\begin{array}{c}\text { Logarithmic-X model: } \\
y=68.58-2.61 \ln x\end{array}$ & 3.6 & $\begin{array}{c}9.7 \\
(0.000)\end{array}$ & $\begin{array}{c}-1.6 \\
(0.110)\end{array}$ & $\begin{array}{c}2.6 \\
(0.110)\end{array}$ & $\begin{array}{c}1.1 \\
(0.000)\end{array}$ \\
\hline
\end{tabular}


this dependence was a linear model in 2015 a logarithmic-X model (Figure 1$)^{2}$. The moderately strong relationship between the fertility rate and the percentage of urban population means that as more and more people start living in cities and towns, less children are born in the country. ered year.
If we divide countries according to their level of economic development in the way described above, we shall see that this relation is more evident in the least developed countries of the world (see Table 3). In less developed countries, this correlation between the fertility rate and the percentage of urban population is also observed, but this relationship is weaker. In more developed countries, this dependence is almost absent.

Results of regression analysis (second and third hypotheses test)

\begin{tabular}{|c|c|c|c|c|c|c|c|c|c|}
\hline \multirow{2}{*}{$\begin{array}{c}\text { Dependent } \\
\text { variable } \\
(y)\end{array}$} & \multirow{2}{*}{$\begin{array}{l}\text { Indepen- } \\
\text { dent vari- } \\
\text { able }(x)\end{array}$} & \multirow[t]{2}{*}{ Year } & \multirow{2}{*}{\begin{tabular}{|} 
Cor- \\
relation \\
coeffi- \\
cient
\end{tabular}} & \multirow[t]{2}{*}{ Regression model } & \multirow{2}{*}{$\underset{\%}{\text { R-squared, }}$} & \multicolumn{2}{|c|}{ T-statistic (P-value) } & \multirow{2}{*}{$\begin{array}{c}\text { F-ratio } \\
\text { (P-value) }\end{array}$} & \multirow{2}{*}{$\begin{array}{l}\text { Durbin- } \\
\text { Watson } \\
\text { statistic } \\
\text { (P-value) }\end{array}$} \\
\hline & & & & & & Intercept & Slope & & \\
\hline \multirow{3}{*}{$\begin{array}{l}\text { Fertility } \\
\text { rate, births } \\
\text { per woman }\end{array}$} & \multirow{3}{*}{$\begin{array}{l}\text { Urban } \\
\text { population, } \\
\text { percentage } \\
\text { of the total } \\
\text { population }\end{array}$} & 1995 & -0.60 & $\begin{array}{l}\text { Linear model: } \\
y=5.9-0.05 x\end{array}$ & 36.2 & $\begin{array}{c}23.5 \\
(0.000)\end{array}$ & $\begin{array}{c}-10.4 \\
(0.000)\end{array}$ & $\begin{array}{c}108.0 \\
(0.000)\end{array}$ & $\begin{array}{c}2.10 \\
(0.803)\end{array}$ \\
\hline & & 2005 & -0.56 & $\begin{array}{l}\text { Linear model: } \\
y=5.2-0.04 x\end{array}$ & 31.7 & $\begin{array}{c}21.1 \\
(0.000)\end{array}$ & $\begin{array}{c}-9.5 \\
(0.000)\end{array}$ & $\begin{array}{c}89.9 \\
(0.000)\end{array}$ & $\begin{array}{c}2.05 \\
(0.645)\end{array}$ \\
\hline & & 2015 & -0.52 & $\begin{array}{c}\text { Logarithmic-X model: } \\
y=83.1-27.6 \ln x\end{array}$ & 27.5 & $\begin{array}{c}25.6 \\
(0.000)\end{array}$ & $\begin{array}{c}-8.5 \\
(0.000)\end{array}$ & $\begin{array}{c}73.1 \\
(0.000)\end{array}$ & $\begin{array}{c}2.10 \\
(0.766)\end{array}$ \\
\hline \multirow[t]{3}{*}{$\begin{array}{l}\text { Fertility } \\
\text { rate, births } \\
\text { per woman }\end{array}$} & \multirow[t]{3}{*}{$\begin{array}{l}\text { Per capita } \\
\text { GDP at cur- } \\
\text { rent prices, } \\
\text { US dollars }\end{array}$} & 1995 & 0.64 & $\begin{array}{l}\text { Reciprocal-X model: } \\
\qquad y=2.7+\frac{594.6}{x}\end{array}$ & 41.1 & $\begin{array}{c}21.4 \\
(0.000)\end{array}$ & $\begin{array}{c}11.1 \\
(0.000)\end{array}$ & $\begin{array}{c}122.2 \\
(0.000)\end{array}$ & $\begin{array}{c}2.0 \\
(0.534)\end{array}$ \\
\hline & & 2005 & 0.70 & $\begin{array}{l}\text { Reciprocal-X model: } \\
y=2.2+\frac{925.6}{x}\end{array}$ & 49.3 & $\begin{array}{c}21.5 \\
(0.000)\end{array}$ & $\begin{array}{c}13.5 \\
(0.000)\end{array}$ & $\begin{array}{c}181.9 \\
(0.000)\end{array}$ & $\begin{array}{c}2.0 \\
(0.626)\end{array}$ \\
\hline & & 2015 & 0.75 & $\begin{array}{c}\text { Reciprocal-X model } \\
y=2.0+\frac{1643.5}{x}\end{array}$ & 56.1 & $\begin{array}{c}24.6 \\
(0.000)\end{array}$ & $\begin{array}{c}15.3 \\
(0.000)\end{array}$ & $\begin{array}{c}233.6 \\
(0.000)\end{array}$ & $\begin{array}{c}2.1 \\
(0.661)\end{array}$ \\
\hline
\end{tabular}

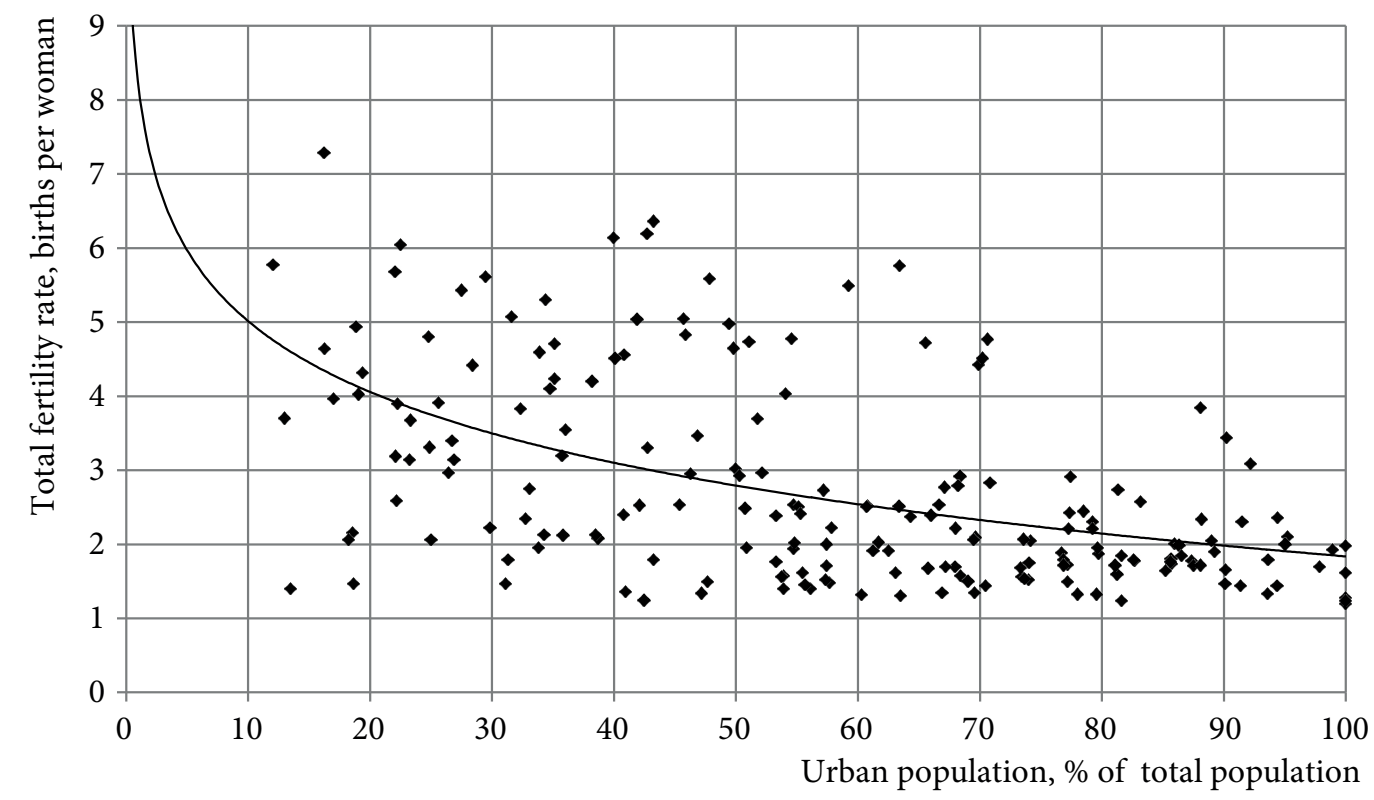

Figure 1. Dependence between the fertility rate and the share of urban population in the total population of a country in 2015

Notes: points denote certain values for countries; the thick solid line denotes a trend line of the logarithmic model 
According to our third hypothesis, poverty and fertility are not correlated. To check this hypothesis, we built a dependence between the fertility rate and per capita GDP (see Table 2 for the results of regression analysis). We found a moderately strong relationship between these two variables. In all the given years, one of the best-fitted models for this dependence was the reciprocal model (Figure 2). A moderately strong nonlinear relationship between these two indicators means that as per capita GDP grows, the fertility rate tends to fall until the definite level of ca. $1.0-2.0$ births per woman.

Results of regression analysis of the dependence between the fertility rate and the percentage of urban population in the total population of a country, divided by the level of its economic development

\begin{tabular}{|c|c|c|c|c|c|c|c|c|}
\hline \multirow[t]{2}{*}{ Year } & \multirow{2}{*}{$\begin{array}{c}\text { Level of eco- } \\
\text { nomic develop- } \\
\text { ment }\end{array}$} & \multirow[t]{2}{*}{$\begin{array}{c}\text { Correlation } \\
\text { coefficient }\end{array}$} & \multirow[t]{2}{*}{ Regression model } & \multirow[t]{2}{*}{ R-squared, } & \multicolumn{2}{|c|}{$\begin{array}{l}\text { T-statistic } \\
\text { (P-value) }\end{array}$} & \multirow[t]{2}{*}{$\begin{array}{c}\text { F-ratio } \\
\text { (P-value) }\end{array}$} & \multirow{2}{*}{$\begin{array}{c}\text { Durbin-Wat- } \\
\text { son statistic } \\
\text { (P-value) }\end{array}$} \\
\hline & & & & & Intercept & Slope & & \\
\hline \multirow[t]{3}{*}{1995} & $\begin{array}{l}\text { Least developed } \\
\text { countries }\end{array}$ & -0.44 & $\begin{array}{l}\text { Linear model: } \\
y=6.2-0.04 x\end{array}$ & 19.4 & $\begin{array}{c}17.4 \\
(0.000)\end{array}$ & $\begin{array}{c}-5.0 \\
(0.000)\end{array}$ & $\begin{array}{c}24.8 \\
(0.000)\end{array}$ & $2.1(0.707)$ \\
\hline & $\begin{array}{l}\text { Less developed } \\
\text { countries }\end{array}$ & -0.38 & $\begin{array}{l}\text { Squared-Y square root-X: } \\
\qquad y=\sqrt{(31.2-2.7 \sqrt{x)}}\end{array}$ & 47.6 & $\begin{array}{c}5.0 \\
(0.000)\end{array}$ & $\begin{array}{c}-3.3 \\
(0.001)\end{array}$ & $\begin{array}{c}11.2 \\
(0.001)\end{array}$ & $1.4(0.007)$ \\
\hline & $\begin{array}{l}\text { More developed } \\
\text { countries }\end{array}$ & 0.05 & $\begin{array}{l}\text { Reciprocal-Y square root-X: } \\
\qquad y=\frac{1}{(0.5+0.01 \sqrt{x)}}\end{array}$ & 0.25 & $\begin{array}{c}1.6 \\
(0.123)\end{array}$ & $\begin{array}{c}0.2 \\
(0.782)\end{array}$ & $\begin{array}{c}0.1 \\
(0.782)\end{array}$ & $2.0(0.5499)$ \\
\hline \multirow[t]{3}{*}{2005} & $\begin{array}{c}\text { Least developed } \\
\text { countries }\end{array}$ & -0.48 & $\begin{array}{l}\text { Square root-Y model: } \\
y=\sqrt{(2.43-0.01 x)}\end{array}$ & 23.3 & $\begin{array}{c}25.3 \\
(0.000)\end{array}$ & $\begin{array}{c}-5.6 \\
(0.000)\end{array}$ & $\begin{array}{c}30.9 \\
(0.000)\end{array}$ & $1.81(0.166)$ \\
\hline & $\begin{array}{l}\text { Less developed } \\
\text { countries }\end{array}$ & -0.21 & $\begin{array}{l}\text { Square root-X model: } \\
y=3.36-0.14 \sqrt{x}\end{array}$ & 4.33 & $\begin{array}{c}4.9 \\
(0.005)\end{array}$ & $\begin{array}{c}-1.7 \\
(0.102)\end{array}$ & $\begin{array}{c}2.8 \\
(0.102)\end{array}$ & $2.1(0.715)$ \\
\hline & $\begin{array}{l}\text { More developed } \\
\text { countries }\end{array}$ & 0.11 & $\begin{array}{l}\text { Squared-Y model: } \\
y=\sqrt{(2.59+0.01 x)}\end{array}$ & 1.3 & $\begin{array}{c}2.2 \\
(0.035)\end{array}$ & $\begin{array}{c}0.7 \\
(0.513)\end{array}$ & $\begin{array}{c}0.4 \\
(0.513)\end{array}$ & $2.0(0.451)$ \\
\hline \multirow[t]{3}{*}{2015} & $\begin{array}{l}\text { Least developed } \\
\text { countries }\end{array}$ & -0.40 & $\begin{array}{l}\text { Exponential model: } \\
\qquad y=4.72 e^{0,01 x}\end{array}$ & 15.9 & $\begin{array}{c}15.7 \\
(0.000)\end{array}$ & $\begin{array}{c}-4.4 \\
(0.000)\end{array}$ & $\begin{array}{c}19.2 \\
(0.000)\end{array}$ & $1.6(0.016)$ \\
\hline & $\begin{array}{l}\text { Less developed } \\
\text { countries }\end{array}$ & 0.09 & $\begin{array}{l}\text { Square root-X model: } \\
y=1.55+0.05 \sqrt{x}\end{array}$ & 0.90 & $\begin{array}{c}2.6 \\
(0.011)\end{array}$ & $\begin{array}{c}0.7 \\
(0.479)\end{array}$ & $\begin{array}{c}0.51 \\
(0.479)\end{array}$ & $1.9(0.348)$ \\
\hline & $\begin{array}{l}\text { More developed } \\
\text { countries }\end{array}$ & 0.05 & $\begin{array}{l}\text { Square root-X model: } \\
y=1.63+0.02 \sqrt{x}\end{array}$ & 0.25 & $\begin{array}{c}3.3 \\
(0.003)\end{array}$ & $\begin{array}{c}0.3 \\
(0.781)\end{array}$ & $\begin{array}{c}0.1 \\
(0.781)\end{array}$ & $1.0(0.001)$ \\
\hline
\end{tabular}

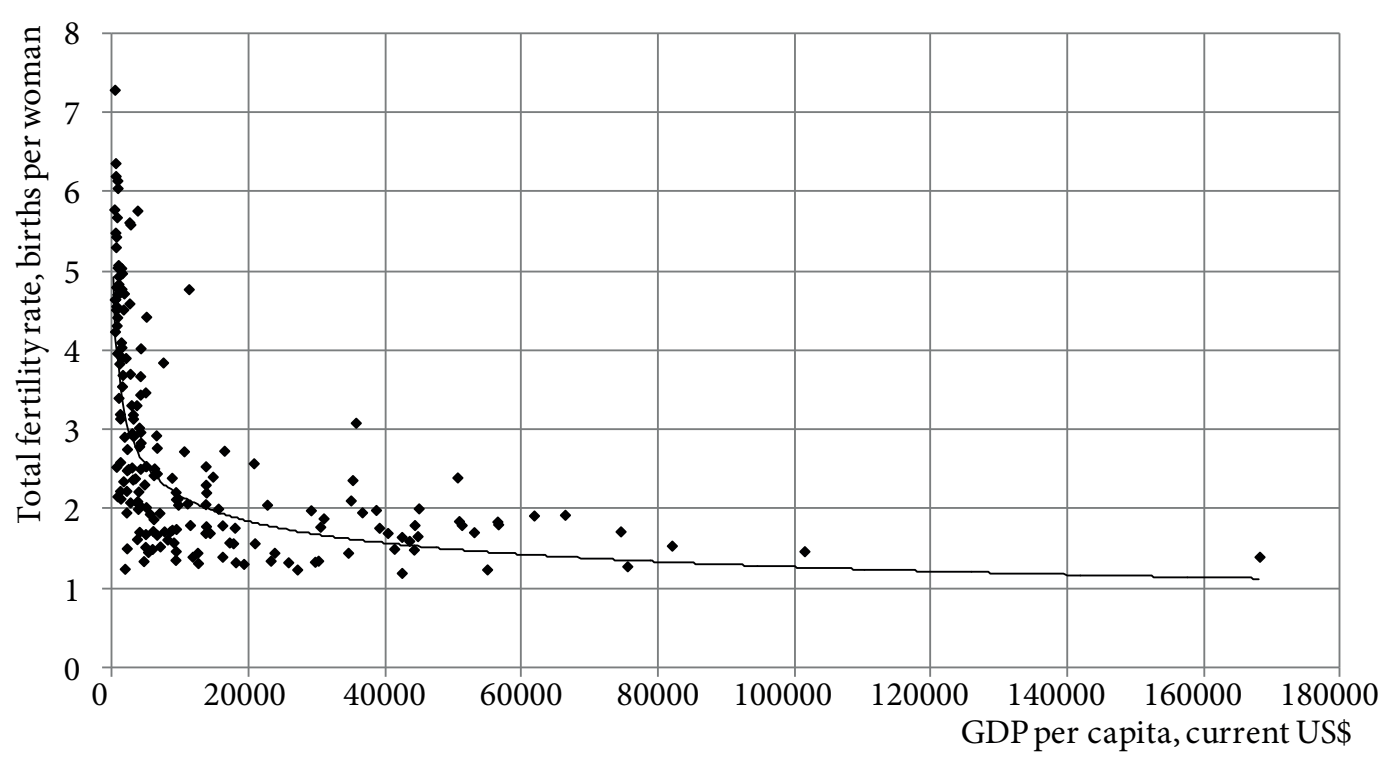

Figure 2. Dependence between the fertility rate and per capita GDP in 2015

Notes: points denote certain values for countries; the thick solid line denotes the trend line of the reciprocal-X model 
According to the fourth hypothesis, population concentration in big cities and the relationship between the birth rates and the infant mortality rates depend on the level of economic development.

To check this hypothesis, we considered the relationships between the following variables:
- the share of population of agglomerations with 1 million inhabitants or more in the country's total population and its per capita GDP;

- the ratio of the birth rate to the infant mortality rate and per capita GDP.

According to the results of regression analysis (see Table 4), for the given years, a polynomial

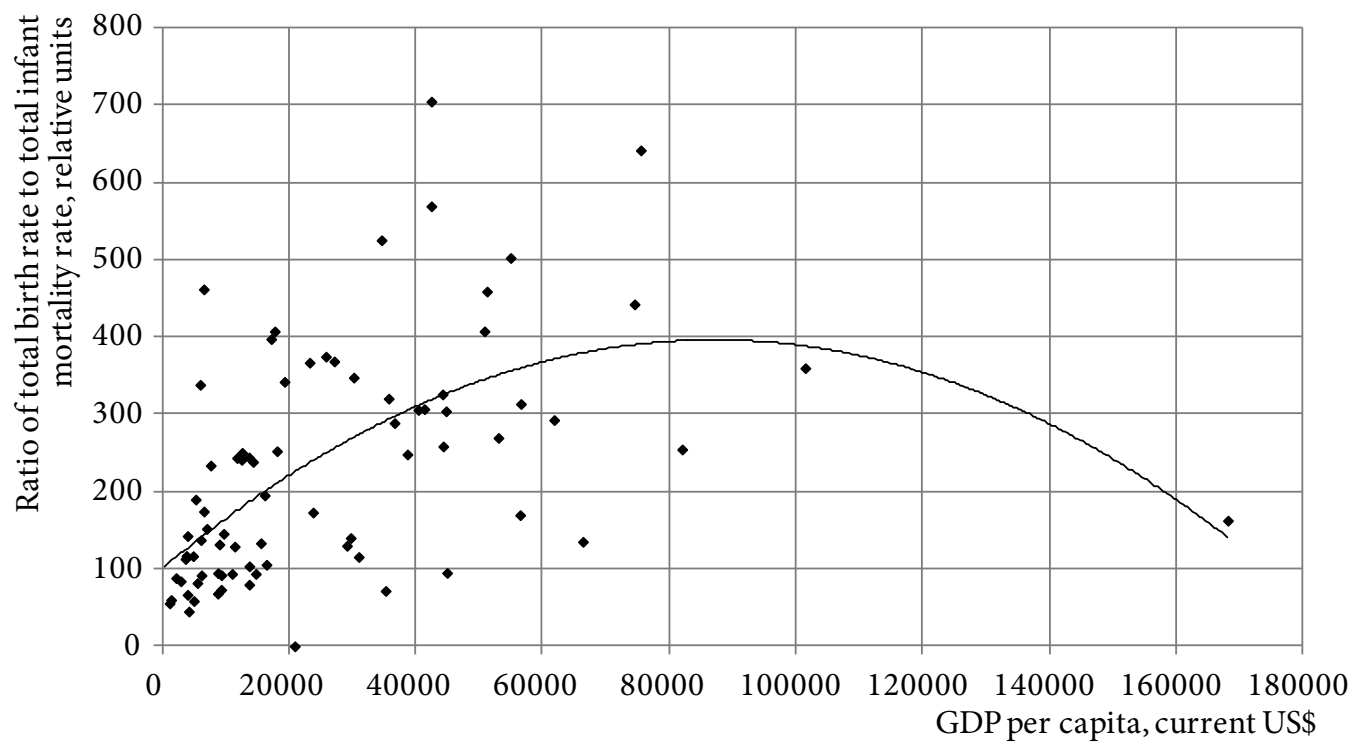

Figure 3. Dependence between the share of population of agglomerations with 1 million inhabitants or more in the total population of a country and its per capita GDP in 2015

Notes: points denote certain values for countries; the thick solid line denotes the trend line of the polynomial model of the second order

Results of regression analysis (fourth hypothesis test)

\begin{tabular}{|c|c|c|c|c|c|c|c|c|c|}
\hline \multirow{2}{*}{$\begin{array}{c}\text { Dependent } \\
\text { variable } \\
(y)\end{array}$} & \multirow{2}{*}{$\begin{array}{l}\text { Inde- } \\
\text { pendent } \\
\text { variable } \\
(x)\end{array}$} & \multirow[t]{2}{*}{ Year } & \multirow[t]{2}{*}{ Regression model } & \multirow{2}{*}{$\begin{array}{l}\text { R-squa- } \\
\text { red, \% }\end{array}$} & \multicolumn{3}{|c|}{ T-statistic (P-value) } & \multirow{2}{*}{$\begin{array}{c}\text { F-ratio } \\
\text { (P-value) }\end{array}$} & \multirow{2}{*}{$\begin{array}{l}\text { Durbin- } \\
\text { Watson } \\
\text { statistic } \\
\text { (P-value) }\end{array}$} \\
\hline & & & & & $\begin{array}{l}\text { Con- } \\
\text { stant }\end{array}$ & $\begin{array}{l}\text { Parame- } \\
\text { ter } x\end{array}$ & $\begin{array}{c}\text { Parame- } \\
\text { ter } x^{2}\end{array}$ & & \\
\hline \multirow{3}{*}{$\begin{array}{l}\text { Population } \\
\text { of agglom- } \\
\text { erations } \\
\text { with 1 } \\
\text { million } \\
\text { inhabitants } \\
\text { or more, } \\
\text { percentage } \\
\text { of the total } \\
\text { population }\end{array}$} & \multirow{3}{*}{$\begin{array}{l}\text { Per capita } \\
\text { GDP at } \\
\text { current } \\
\text { prices, US } \\
\text { dollars }\end{array}$} & 1995 & $\begin{array}{l}\text { Polynomial model of the second } \\
\text { order: } \\
y=14.8+0.002 x-5.22 \cdot 10^{-8} x^{2}\end{array}$ & 30.1 & $\begin{array}{c}7.7 \\
(0.000)\end{array}$ & $\begin{array}{c}6.0 \\
(0.000)\end{array}$ & $\begin{array}{c}-4.6 \\
(0.000)\end{array}$ & $\begin{array}{c}22.6 \\
(0, .000)\end{array}$ & $\begin{array}{c}2.0 \\
(0.415)\end{array}$ \\
\hline & & 2005 & $\begin{array}{l}\text { Polynomial model of the second } \\
\text { order: } \\
y=14.53+0.003 x-4.91 \cdot 10^{-8} x^{2}\end{array}$ & 33.9 & $\begin{array}{c}7.5 \\
(0.000)\end{array}$ & $\begin{array}{c}6.7 \\
(0.000)\end{array}$ & $\begin{array}{c}-5.7 \\
(0.000)\end{array}$ & $\begin{array}{c}27.4 \\
(0.000)\end{array}$ & $\begin{array}{c}1.9 \\
(0.224)\end{array}$ \\
\hline & & 2015 & $\begin{array}{l}\text { Polynomial model of the second } \\
\text { order: } \\
y=15.21+0.001 x-1.63 \cdot 10^{-8} x^{2}\end{array}$ & 28.1 & $\begin{array}{c}7.1 \\
(0.000)\end{array}$ & $\begin{array}{c}5.3 \\
(0.000)\end{array}$ & $\begin{array}{c}-3.8 \\
(0.000)\end{array}$ & $\begin{array}{c}21.0 \\
(0.000)\end{array}$ & $\begin{array}{c}1.8 \\
(0.156)\end{array}$ \\
\hline \multirow{3}{*}{$\begin{array}{l}\text { Ratio of } \\
\text { the birth } \\
\text { rate to } \\
\text { the infant } \\
\text { mortality } \\
\text { rate, rela- } \\
\text { tive units }\end{array}$} & \multirow{3}{*}{$\begin{array}{l}\text { Per capita } \\
\text { GDP at } \\
\text { current } \\
\text { prices, US } \\
\text { dollars }\end{array}$} & 1995 & $\begin{array}{l}\text { Polynomial model of the second } \\
\text { order: } \\
y=33.73+0.01 x-1.92 \cdot 10^{-7} x^{2}\end{array}$ & 90.5 & $\begin{array}{c}4.6 \\
(0.000)\end{array}$ & $\begin{array}{c}8.4 \\
(0.000)\end{array}$ & $\begin{array}{c}-5.9 \\
(0.008)\end{array}$ & $\begin{array}{c}86.2 \\
(0.000)\end{array}$ & $\begin{array}{c}2.4 \\
(0.844)\end{array}$ \\
\hline & & 2005 & $\begin{array}{l}\text { Polynomial model of the second } \\
\text { order: } \\
y=72.27+0.006 x-3.00 \cdot 10^{-8} x^{2}\end{array}$ & 53.5 & $\begin{array}{c}6.1 \\
(0.000)\end{array}$ & $\begin{array}{c}6.4 \\
(0.000)\end{array}$ & $\begin{array}{c}-2.5 \\
(0.016)\end{array}$ & $\begin{array}{c}56.9 \\
(0.000)\end{array}$ & $\begin{array}{c}2.0 \\
(0.553)\end{array}$ \\
\hline & & 2015 & $\begin{array}{l}\text { Polynomial model of the second } \\
\text { order: } \\
y=100.33+0.007 x-3.89 \cdot 10^{-8} x^{2}\end{array}$ & 34.1 & $\begin{array}{c}4.1 \\
(0.000)\end{array}$ & $\begin{array}{c}5.9 \\
(0.000)\end{array}$ & $\begin{array}{c}-4.4 \\
(0.000)\end{array}$ & $\begin{array}{c}19.4 \\
(0.000)\end{array}$ & $\begin{array}{c}1.7 \\
(0.131)\end{array}$ \\
\hline
\end{tabular}


model of the second order fits the first dependence best of all (Figure 3). The polynomial dependence between the considered variables means that the highest concentration of population in big cities is more typical of less developed countries. In the least developed and more developed countries, the share of the population living in urban agglomerations with 1 million inhabitants or more is not as high as in less developed countries. In other words, at first, the concentration of urban population grows together with the economic growth of the country, but after reaching a certain level of per capita GDP (ca. 23000 US dollars in 1995, ca. 25000 US dollars in 2005, and ca. 40000 US dollars in 2015), this concentration gradually declines.

The best trend line fitting the dependence between the ratio of the birth rate to the infant mortality rate and per capita GDP is also described by a polynomial model of the second order (Figure 4). The polynomial model shows us that at first with per capita GDP growth the ratio of the birth rate to the infant mortality rate also increases, but after a certain value of per capita GDP (ca. 34000 US dollars in 1995, ca. 80000 US dollars in 2005, and ca. 95000 US dollars in 2015), it begins to decrease. In less developed countries, this ratio is higher in comparison with the least and more developed countries. In the least developed countries, this ratio is low because of the high infant mortality rate, and in more developed countries this ratio is comparatively low because of the low birth rate.

\section{Conclusion}

The aim of this research was to investigate how strongly the biological factor (acting alongside economic factors) affects urban growth. Therefore, we have formulated the following hypotheses:

Hypothesis 1: There is a direct relationship between the population density and urban growth.

Hypothesis 2: Urban population growth is accompanied by a fall in the fertility rate.

Hypothesis 3: There is no correlation between poverty and fertility.

Hypothesis 4: Population concentration in big cities and the relationship between the birth rates and the infant mortality rates depend on the level of economic development.

To test these hypotheses, we applied methods of regression analysis and found that the second and the fourth hypotheses were partially confirmed. The first and the third hypotheses were refuted.

The first hypothesis is refuted, because in the given years no statistically significant relationship between urban growth (urbanization) and population density was discovered. It is worth mentioning one more time that we used the national statistical data and, therefore, population density was considered for a country rather than a region

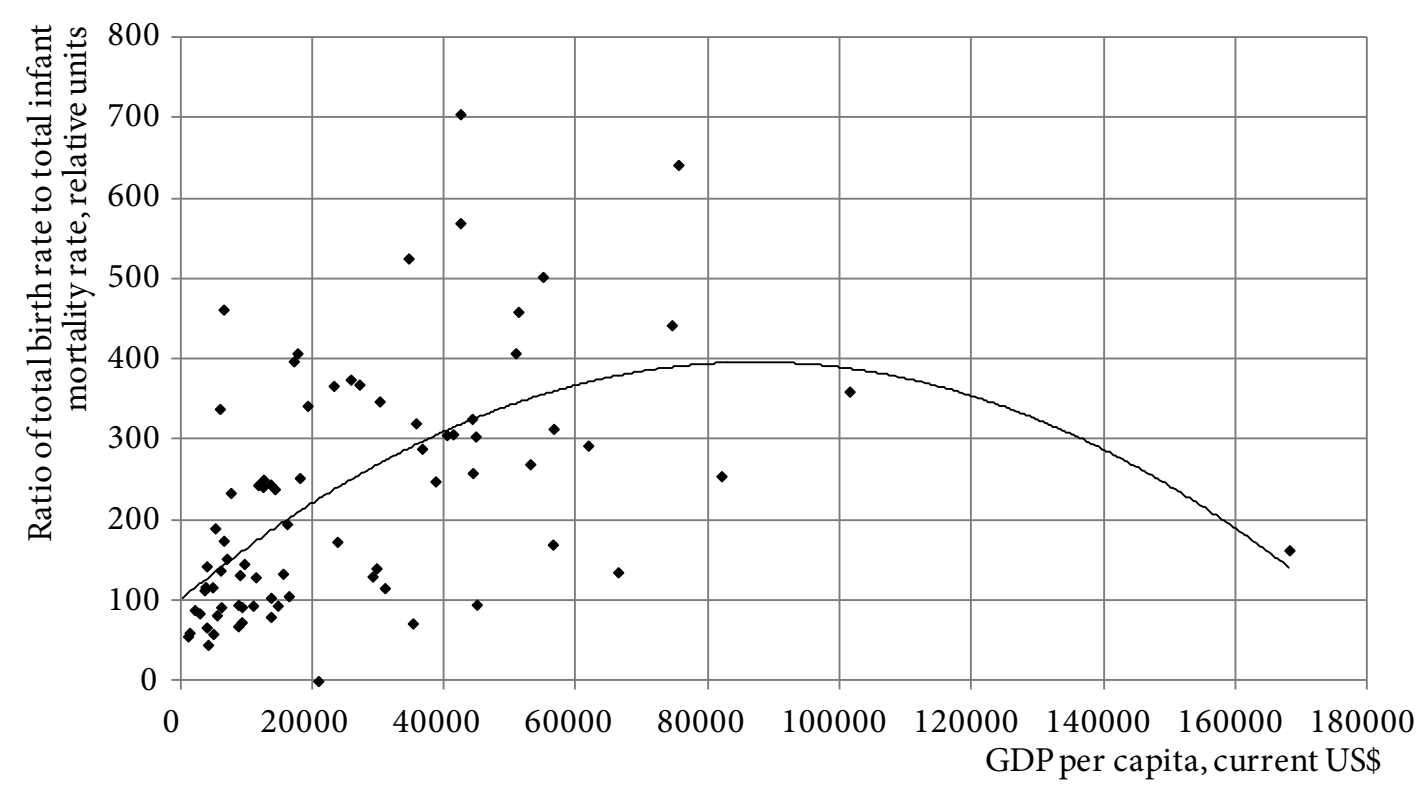

Figure 4. Dependence between the ratio of the birth rate to the infant mortality rate of a country and its per capita GDP in 2015

Notes: points denote certain values for countries; the thick solid line denotes the trend line of the polynomial model of the second order 
or a city. Therefore, there is a need for further analysis using the data on population density on the level of individual cities. Even on a national level, when city states, such as Macao or Hong Kong, are taken into consideration, the existence of these relationships is proved. For example, in the regions with extremely high population density (Monaco, Singapore and Chinese special administrative regions - Macao and Hong Kong), the fertility rate is low - it does not exceed the level of 2.0 births per woman.

The second hypothesis is confirmed. We found a moderately strong relationship between the fertility rate and the share of urban population in the total population of a country in the given years. As more and more people start living in cities and towns, less children are born in the country. This relation is more evident in the least developed countries of the world. In more developed countries, this dependence is almost absent. For better understanding of this relationship, analysis of the data on the level of individual cities is needed.

The results of regression analysis did not confirm the third hypothesis. We found a moderately strong nonlinear relationship between the fertility rate and per capita GDP. The growth in per capita GDP is accompanied by a decline in the fertility rate until the definite level of ca. 1.0-2.0 births per woman. This observation contradicts the opinion of Dolnik [7] cited above. In other words, the level of a country's economic development directly influences its fertility rate. Our analysis has shown that economic growth is not the sole factor affecting fertility but it is among the most important ones.

Finally, the fourth hypothesis was confirmed. The regression analysis revealed the polynomial form (of the second order) of the dependence between the share of population of agglomerations with 1 million inhabitants or more in the total population of a country and its per capita GDP. It means that in the least developed and more developed countries, the share of population living in urban agglomerations with 1 million inhabitants or more is not as high as in less developed countries. The peak of concentration of the population in big cities is observed at the mean level of economic development of a country.

Is there an equilibrium between the birth rates and infant mortality rates in more developed countries, which can thus be described as sustainable populations? To answer these ques- tions, we considered the dependence between the ratio of the birth rate to the infant mortality rate and per capita GDP. We found that this relationship is also better described by a polynomial model of the second order. In less developed countries, this ratio is higher in comparison with the least and more developed countries. In the least developed countries, high infant mortality rates compensate for high birth rates. A rapid decline in the infant mortality rate due to humanitarian aid led to the unrestrained population growth in developing countries. Only more developed countries have managed to find a new balance between the birth rates and infant mortality rates. Therefore, we can conclude that the population of developed countries can be described as sustainable in this sense.

The results of this research show that the biological factors of urban development should be considered on a par with economic ones. Therefore, a comprehensive analysis of different factors of urban development is needed. Biological mechanisms affecting urban population play a significant role in the least and less developed countries, where the fertility rates vary significantly. Nevertheless, they start to decrease gradually along with the population growth. In more developed countries with high levels of per capita GDP, less than $60-70 \%$ of people live in cities with the population of 1 million inhabitants or more and the fertility rate does not exceed the simple reproduction level of 2.1 births per woman ${ }^{3}$.

As we have pointed out above, this research used the national-level data, so the next step in this direction would be to look at the city-level data. Further analysis may also expand the range of socio-economic factors by considering per capita incomes, social security, the level of education, life expectancy, etc. This could be an important contribution to this research, taking into account the current approach to GDP estimation and the fact that service industries, which usually concentrate in urban areas, bring the biggest added value and make a considerable contribution to GDP formation.

\footnotetext{
3 The level of simple reproduction is an average number of children who should be born in order to numerically substitute active generations who are giving births. The total fertility rate of 2,1 is widely used as a simple reproduction level.
} 


\section{References}

1. Abdel-Rahman, H. M., \& Anas, A. (2004) Theories of systems of cities. In: J. V. Henderson, J.-F. Thisse (Eds.) Handbook of Regional and Urban Economics, Volume 4: Cities and Geography (pp. 2293-2339). New York: Elsevier Science.

2. Mabogunje, A. L. (1970) Systems approach to a theory of rural-urban migration. Geographical Analysis, 2(1), pp. 1-18.

3. Goldsmith, P. D., Gunjal, K., \& Ndarishikanye, B. (2004) Rural-urban migration and agricultural productivity: the case of Senegal, Agricultural Economics, 31(1), pp. 33-45.

4. Fujita, M., \& Thisse, J.-F. (2002) Economics of Agglomeration: Cities, Industrial Location, and Regional Growth. Cambridge: Cambridge University Press.

5. Lindblad, Y. (1991) Man - you, me and primeval: Human evolution. Moscow: Progress. (In Russ.)

6. Sachs, J. (2008) Common Wealth: Economics for a Crowded Planet. New York: Penguin Press.

7. Dolnik, V. R. (2004) Disobedient child of the biosphere. Conversations about human behavior in the company of birds, beasts and children. Saint-Petersburg: CheRo-na-Neve, Petroglif. (In Russ.)

8. Chauvin, R. (1968) Animal Societies from the Bee to the Gorilla. New York: Hill \& Wang.

9. Wynne-Edwards, V. C. (1986) Evolution Through Group Selection. Oxford: Blackwell Scientific.

10. Kurchanov, N. A. (2012) Behaviour: evolutional approach. Saint-Petersburg: SpecLit. (In Russ.)

11. Calhoun, J. B. (1962) Population density and social pathology, Scientific American, 206(2), pp. 139-150.

12. Carey, J. R., Liedo, P., \& Vaupel, J.W. (1995) Mortality dynamics of density in the Mediterranean fruit fly, Experimental Gerontology, 30(6), pp. 605-629.

13. Chauvin, R. (2009) Animals' behaviour. Moscow: URSS: LIBROCOM. (In Russ.)

14. Ramsden, E., \& Adams, J. (2009) Escaping the laboratory: the rodent experiments of John B. Calhoun \& their cultural influence, The Journal of Social History, 42(3), pp. 761-792.

15. Freedman, J. L. (1975) Crowding and Behaviour. San Francisco: W. H. Freeman.

16. Moore, J. (1999) Population density, social pathology, and behavioral ecology, Primates, 40(1), Special Edition: Primate Socioecology, pp. 1-22.

17. Morris, D. (1996) The Human Zoo: A Zoologist's Study of the Urban Animal. New York: Kodansha America, Inc.

18. Lorenz, K. (1974) Civilized Man's Eight Deadly Sins. London: Methuen \& co.

19. Cacioppo, J. T., McClintock, M. K., Berntson, G. G., \& Sheridan, J. F. (2005) Multilevel integrative analyses of human behavior: social neuroscience and the complementing nature of social and biological approaches, Psychological Bulletin, 126(6), pp. 829-843.

20. Morris, D. (2015) The Naked Ape: A Zoologist's Study of the Human Animal. London: Random House.

21. Kulu, H. (2013) Why do fertility levels vary between urban and rural areas? Regional Studies, 47(6), pp. 895-912. DOI: $\underline{10.1080 / 00343404.2011 .581276}$

22. Newell, A., \& Gazeley, I. (2012) The declines in infant mortality and fertility: Evidence from British cities in demographic transition, Economics Department Working Paper Series, University of Sussex, No. 48-2012.

23. Ushie, M. A., Ogaboh, Agba A. M., Olumodeji, E. O., \& Attah, F. (2011) Socio-cultural and economic determinants of fertility differentials in rural and urban Cross Rivers State, Nigeria, Journal of Geography and Regional Planning, 4(7), pp. 383-391.

24. Fox, J., \& Myrskylä, M. (2011) Urban fertility responses to local government programs: evidence from the 1923-1932 U.S., Max Planck Institute for Demographic Research.

25. Bonoli, G. (2008) The impact of social policy on fertility: evidence from Switzerland, Journal of European Social Policy, 18(1), pp. 64-78. DOI: 10.1177/0958928707081074 


\section{Information about the author}

Nadezhda V. Shcherbakova - Chief Specialist of Socio-Economic Research Department of Scientific Research and Design Institute of Territorial Development and Transport Infrastructure (4, letter K, Fuchika Str., 192102, St. Petersburg, Russia); e-mail: nadshch@mail.ru

ARTICLE INFO: received June 06, 2019; accepted August 13, 2019

\section{Информация об авторе}

Щербакова Надежда Викторовна - главный специалист Департмамента социальноэкономических исследований Научно-исследовательского и проектного института территориального развития и транспортной инфраструктуры (192102, Россия, г. Санкт-Петербург, ул. Фучика, 4, литера K); e-mail: nadshch@mail.ru

ИНФОРМАЦИЯ О СТАТЬЕ: дата поступления 6 июня 2019 г.; дата принятия к печати 13 августа 2019 г.

This work is licensed under a Creative Commons Attribution 4.0 International License

Эта работа лицензируется в соответствии с Creative Commons Attribution 4.0 International License 